\section{Identifying Opportunities to Promote Water Treatment Practices among Nursery and Greenhouse Growers}

\author{
Alexa J. Lamm ${ }^{1}$, Laura A. Warner ${ }^{2}$, Peyton Beattie ${ }^{2}$, \\ Abraham Tidwell ${ }^{1}$, Paul R. Fisher ${ }^{3}$, and Sarah A. White ${ }^{4}$
}

ADDITIONAL INDEX WORDS. audience analysis, best management practices, irrigation, technology adoption

SUMMARY. There are many water treatment technologies available to the nursery and greenhouse industry, but this sector has been somewhat hesitant to adopt them. An online survey was used to evaluate nursery and greenhouse growers' knowledge, implementation, and continued use of 12 water treatment technologies. Less than $\mathbf{2 4 \%}$ of the growers had used a water treatment technology. The knowledge level was low overall, and fewer than one in four growers had implemented all 12 technologies. However, most growers who had implemented 10 of the 12 technologies continued to use them. The results imply water treatment technologies available for this group are somewhat unknown and underused, thereby implying that there is a need to increase awareness of these innovations and highlight the opportunity for growers to advocate for treatment technology use among their peers.

$\mathrm{E}$ fficient development and management of water resources in the agricultural sector is critical for promoting global security, alleviating poverty, and generating human well-being (Grey and Sadoff, 2007). Global agricultural sector water use accounts for $70 \%$ of the world's freshwater withdrawals and is expected to continue to increase through 2050 (Tran et al., 2016). Agricultural water use is inexorably linked to a host of other factors pertaining to human

Received for publication 11 Dec. 2018. Accepted for publication 30 July 2019.

Published online 20 September 2019

${ }^{1}$ University of Georgia, Department of Agricultural Leadership, Education and Communication, 132 Four Towers, Athens, GA 30602

${ }^{2}$ University of Florida, Department of Agricultura Education and Communication, P.O. Box 112060 , Gainesville, FL 32611

${ }^{3}$ University of Florida, Environmental Horticulture Department, P.O. Box 110670, Gainesville, FL 32611

${ }^{4}$ Clemson University, Department of Plant and Environmental Sciences, E-143 Poole and Agricultural Sciences, Clemson, SC 29634

This material is based on work that was supported by the National Institute of Food and Agriculture, U.S. Department of Agriculture, under award number 2014-51181-22372.

This paper is based on information presented during the Clean WateR3 program sessions, which were held as part of the ASHS Annual Conference, 30 July-3 Aug. 2018, in Washington, DC.

A.J.L. is the corresponding author. E-mail: alamm@ uga.edu.

This is an open access article distributed under the CC BY-NC-ND license (https://creativecommons.org/ licenses/by-nc-nd/4.0/).

https://doi.org/10.21273/HORTTECH04245-18 well-being, such as nutrition, health, ecosystem degradation, and energy (Bakker, 2012). The nursery and greenhouse industry has a high water requirement based on its volume per unit area of production, and its reliance on groundwater sources is increasing (Fulcher et al., 2016). The water volume required to irrigate floriculture crops ranges from 240 to $320 \mathrm{gal} / 1000 \mathrm{ft}^{2}$ per day in a standard commercial greenhouse (Bartok, 2009 ), and the volume of water used to irrigate container nursery crops averages more than 27,000 gal/acre per day if $1 \mathrm{inch} / \mathrm{d}$ of water is applied (Fulcher et al., 2016). The large amounts of surface water and groundwater used for irrigation place pressure on the industry to find alternative water sources and to implement production systems that conserve water and capture and reuse runoff (Bixio et al., 2006). This study focuses on how greenhouse and nursery growers are implementing water treatment technologies when managing their water resources.

Water treatment has been described by Raudales et al. (2014a) as treating water for pathogens, algae, and biofilm to ensure that the water is safe for reuse. Water treatment technologies allow growers to be efficient with the limited amount of water resources available and to ensure that the water they return to the environment has a low level of contaminants such as nutrients and pesticides (Majsztrik et al., 2017; Raudales et al., 2014a). The adoption of water treatment technologies by nursery and greenhouse growers can have positive long-term impacts on the environment, the health of crops grown in nurseries or greenhouses, and the amount of water used (Majsztrik et al., 2017).

Although water treatment technologies have a positive impact on the environment, nursery and greenhouse growers are hesitant to adopt these technologies (Yeager et al., 2010). Grower hesitation to use water recirculation and treatment practices stems from the costs associated with the installation and long-term maintenance of water treatment technologies (Bixio et al., 2006) and the possibility of pathogen transfer to other plants through irrigation if the water is not treated properly (Majsztrik et al., 2017; Raudales et al., 2014b; White, 2013; Wilson et al., 2010).

Warner et al. (2018) identified the conservation technologies that growers have chosen to adopt and use in their operations, and they determined that a large percentage of growers are using conservation techniques such as drip irrigation. However, to recycle and reuse water (an important part of the water conversation), the adoption of treatment technology must be explored. Wilson and von Broembsen (2017) found that the growers they were working with experienced positive results when they implemented treatment technologies and planned to continue their use. This research provided an overview of which treatment technologies growers have chosen to adopt and use on a larger scale. Understanding the adoption of novel technologies within a social group is a necessary first step in

\begin{tabular}{llll}
\hline $\begin{array}{l}\text { Units } \\
\text { To convert U.S. to SI, } \\
\text { multiply by }\end{array}$ & U.S. unit & SI unit & $\begin{array}{l}\text { To convert SI to U.S., } \\
\text { multiply by }\end{array}$ \\
\hline 407.4583 & gal $/ 1000 \mathrm{ft}^{2}$ & $\mathrm{~L} \cdot \mathrm{ha}^{-1}$ & 0.0025 \\
9.3540 & gal $/ \mathrm{acre}$ & $\mathrm{L} \cdot \mathrm{ha}^{-1}$ & 0.1069 \\
2.54 & inch $(\mathrm{es})$ & $\mathrm{cm}$ & 0.3937
\end{tabular}

Hortlechnology · December 2019 29(6) 
supporting the group's diffusion process. Research and extension personnel who support nursery and greenhouse growers need to understand how individuals in this sector gain knowledge about new technologies, observe their implementation within their social networks, and incorporate the technologies into their production practices if relevant to their activities (Rogers, $2003)$. This process of incorporation can involve continuing to use a technology as designed, rejecting its use entirely in favor of an alternative (newer or older) option, or redesigning the technology to suit specific needs (Kline and Pinch, 1996). This study leverages the diffusion of an innovation model to identify and quantify three critical elements of the water treatment technology adoption cycle: grower level of knowledge as it pertains to these technologies, which technologies (if any) they have chosen to adopt, and the number of those technologies that they have adopted that are still being used in their operations.

\section{Materials and methods}

STUdy Population. Data were collected from nursery and greenhouse growers across the United States through a researcher-developed online survey. Responses were collected through an online survey platform (Qualtrics; Salt Lake City, UT) from Jan. through Apr. 2017. The population of interest included 1170 nursery and greenhouse growers who had previously responded to a national nursery growers information survey and provided their e-mail addresses. A limitation of the study was that the growers could only be contacted via e-mail. However, it was decided that these individuals are most likely to adopt new technologies (broadly speaking); therefore, they were the initial target audience. A $16.4 \%$ response rate was obtained $(\mathrm{N}=192)$. Gender, size of operation, and geographic location of the respondents were compared with those of nonrespondents using a chi-square test. There were no significant differences between respondents and nonrespondents, indicating that the sample obtained was representative of the population of interest. Full demographics of the respondents are detailed in Table 1.

InSTRUMENTATION. Twelve water treatment technologies to be assessed through this research were chosen by nursery, greenhouse, and extension specialists. The water treatment technologies were as follows:

1) Vegetated buffers/riparian buffers for sediment and nutrient removal. Buffers are areas of permanent vegetation located within and between production areas and the water body to which they drain. Buffers intercept and slow runoff, permitting settling of sediment and sediment-bound contaminants (Majsztrik et al., 2017).

2) Vegetated channel for sediment/nutrient removal. Vegetated channels are water conveyance structures lined with emergent wetland

Table 1. Demographic characteristics of the 192 nursery and greenhouse growers responding to a survey in 2017.

\begin{tabular}{|c|c|}
\hline & Grower responses (\%) \\
\hline \multicolumn{2}{|l|}{ Sex } \\
\hline Female & 26.4 \\
\hline Male & 73.6 \\
\hline \multicolumn{2}{|l|}{ Race } \\
\hline African American & 0.0 \\
\hline Asian or Pacific Islander & 1.5 \\
\hline Caucasian/White & 60.9 \\
\hline Native American & 1.5 \\
\hline \multicolumn{2}{|l|}{ Ethnicity } \\
\hline Hispanic/ Latino & 1.6 \\
\hline \multicolumn{2}{|l|}{ Age (years) } \\
\hline $18-24$ & 0.8 \\
\hline $25-34$ & 4.7 \\
\hline $35-44$ & 10.9 \\
\hline $45-54$ & 20.9 \\
\hline $55-64$ & 42.6 \\
\hline $65-74$ & 16.3 \\
\hline 75 and older & 3.9 \\
\hline \multicolumn{2}{|l|}{ Education } \\
\hline High school graduate & 5.4 \\
\hline Some college education & 19.4 \\
\hline 2-year college degree & 12.4 \\
\hline 4-year college degree & 35.7 \\
\hline Graduate degree & 27.1 \\
\hline \multicolumn{2}{|l|}{ Operations gross annual sales } \\
\hline$\$ 10,000-\$ 99,999$ & 44.2 \\
\hline$\$ 100,000-\$ 499,999$ & 14.0 \\
\hline$\$ 500,000-\$ 999,999$ & 7.8 \\
\hline$\$ 1,000,000-\$ 9,999,999$ & 20.2 \\
\hline$\$ 10,000,000$ or more & 14.0 \\
\hline \multicolumn{2}{|l|}{ Region of the United States } \\
\hline Northeast & 20.9 \\
\hline South & 43.4 \\
\hline Midwest & 22.5 \\
\hline West & 13.2 \\
\hline
\end{tabular}

vegetation that move water from one location to another, while slowing the water to permit sediment settling (Majsztrik et al., 2017).

3) Chemical treatment of water for pathogen removal. Plant pathogens can be removed from water via chemical reactions (reduction-oxidation, photodegradation) that disrupt organism cell walls and alter DNA or RNA to destroy the pathogens. Examples of chemical water treatment technologies are chlorination, ozonation, peroxides, ultraviolet light, and copper and silver ionization (Raudales et al., 2014a).

4) Physical treatment of water for pathogen removal. Physical treatment involves filtration of water via several mechanisms, including adhesion, flocculation, impaction, interception, and straining (Levine et al., 1985). 


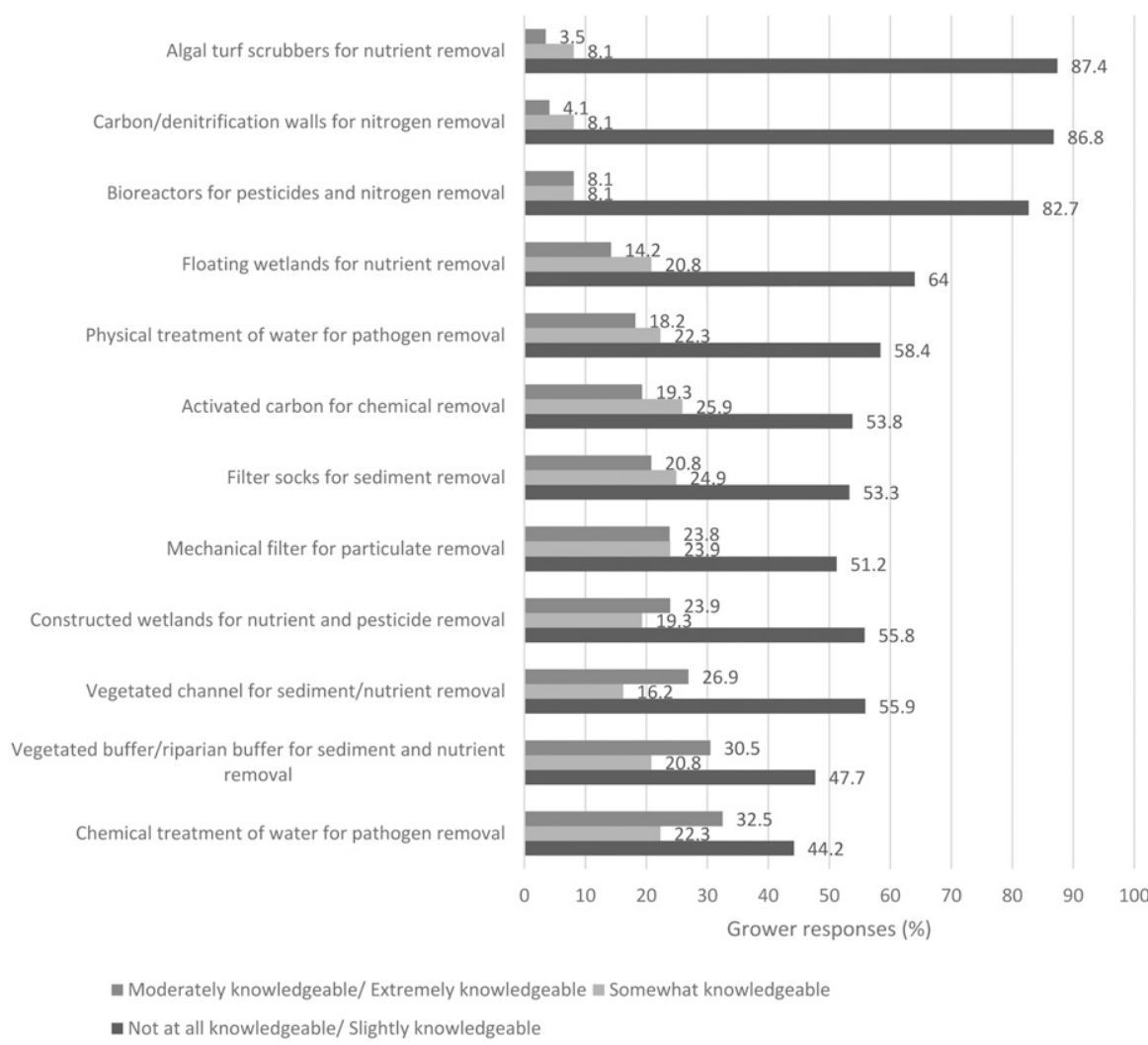

Fig. 1. U.S. nursery and greenhouse growers' perceived knowledge level of water treatment technologies. Values may not total $100 \%$ because some respondents did not respond to every item.

Physical treatment can include rapid filtration (sand/media filters), mechanical filters, activated carbon filters, membrane filters, and filter socks.

$5)$ Mechanical filter for particulate removal. Mechanical filters include disc filters, paper filters, and rotary screens (Majsztrik et al., 2017).

6) Filter socks for sediment removal. Filter socks are long mesh or fabric tubes filled with an organic medium, typically composted wood chips, that can be amended with mineral or organic adsorbents or precipitants to enhance flocculation of sediment. Filter socks have been used by nursery growers as sediment traps, runoff diversion devices, and check dams to manage stormwater runoff and to reduce runoff velocity, preventing sediment loss and movement offsite (Majsztrik et al., 2017).

7) Activated carbon for chemical removal. Activated carbon, also called activated charcoal, is a highly porous adsorptive medium with a well-developed internal pore structure that is manufactured using chemical activation or high-temperature steam activation. Activated carbons are manufactured from coir, peat, hard and soft wood, coal, and various other specialty carbonaceous materials (Bhatnagar et al., 2013).

8 ) Constructed wetlands for nutrient and pesticide removal. Constructed wetlands are engineered systems that combine the influence of vegetation, soils, and microbial communities to improve water quality (White, 2013).

9) Floating wetlands for nutrient removal. Floating wetlands are modified constructed wetlands suspended on the surface of a water body using a buoyant material. Plant crowns are suspended above the water surface while the entire plant root system is submerged within the water column (White, 2013).

10) Bioreactors for nitrogen and pesticide. Bioreactors are typically edge-of-field treatment practices designed to reduce the presence of nitrate and pesticides in runoff. They are typically designed as subsurface trenches that are filled with a carbon source (wood chips, mulch, or carbon from other waste sources) or an artificial medium that provides surface area for microbial communities to colonize. The microbial communities colonizing the artificial medium or carbon source facilitate contaminant remediation (Majsztrik et al., 2017).

11) Carbon/denitrification walls for nitrogen removal. These walls comprise a type of bioreactor (defined previously) that is a traditional reactive barrier (carbon-based) inserted vertically into the ground that intercepts groundwater flow. Microbial communities colonizing the system break-down contaminants within the water (Schmidt and Clark, 2012)

12) Algal turf scrubbers for nutrient removal. Algal turf scrubbers are ecological treatment systems that use the growth of algae attached to a screen to treat water. The algae absorb inorganic compounds from water that flows over them as a pulsed or continuous sheet flow. The harvest of the algal biomass from algal turf scrubbers is an important component of these treatment systems (Ray et al., 2015).

Three questions were used to meet the objectives of the study. The first question asked respondents to indicate their current knowledge as it related to the 12 aforementioned water treatment technologies. The respondents indicated their level of knowledge using a 5-point Likerttype scale $(1=$ not at all knowledgeable; 2 = slightly knowledgeable; 3 = somewhat knowledgeable; $4=$ moderately knowledgeable; 5 = extremely knowledgeable). The second question asked respondents to indicate which of those water treatment technologies or practices they had implemented. The respondents were given a list of the 12 water treatment technologies as answer options, and respondents were allowed to indicate all that applied. The third question asked respondents to select those technologies that were still in use at their operation at the time of the survey (2017). The respondents were given a list of only those water treatment technologies that they had indicated they implemented from the previous question as answer options; again, respondents were allowed to indicate all that applied.

Face and content validity of the instrument was determined by a panel of water-focused extension professionals 


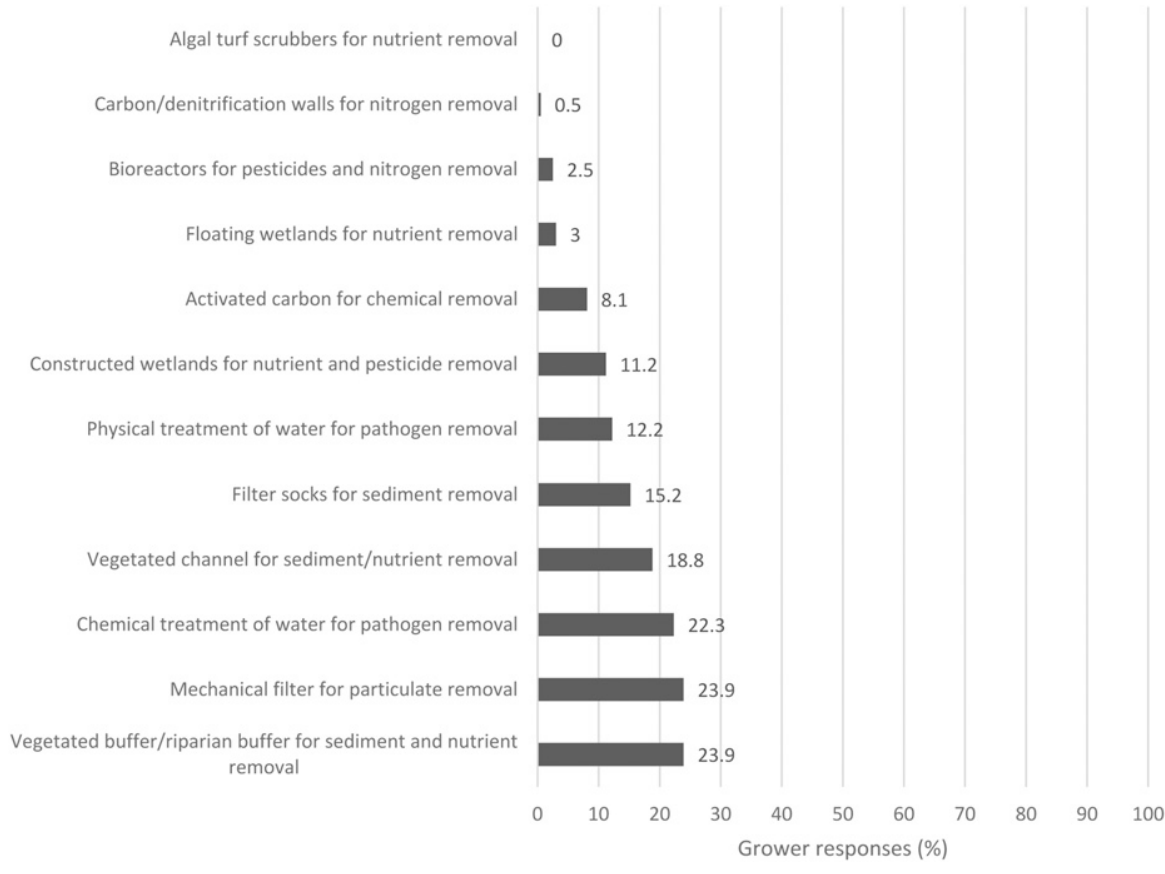

Fig. 2. Percent of nursery and greenhouse growers implementing water treatment technologies in the United States.

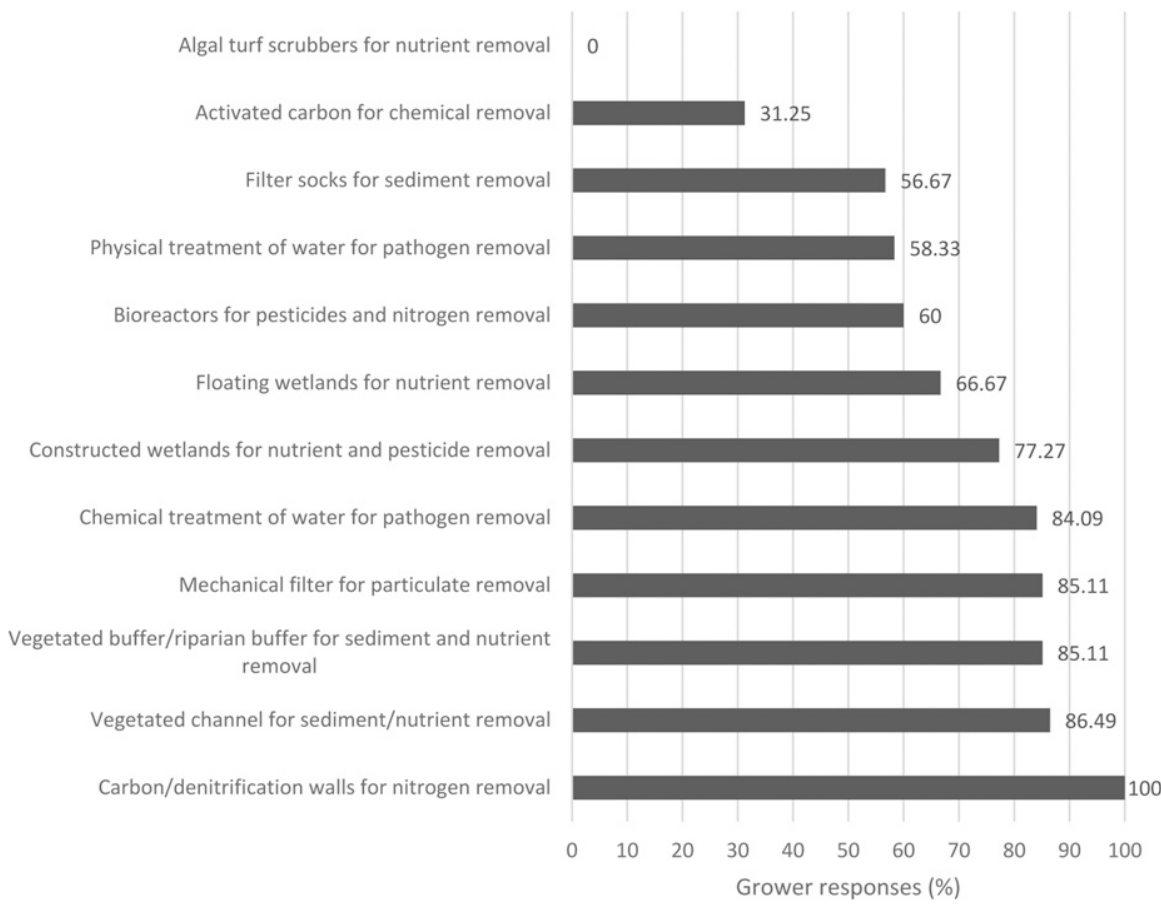

Fig. 3. Percent of nursery and greenhouse growers who implemented water treatment technologies and are still using them, indicating adoption, in the United States.

and agricultural communications, agricultural and biological engineering, and survey methodology experts (Field, 2013; Hardesty and Bearden, 2004; Haynes et al., 1995). Face (content instrument alignment) validity ensured that the instrument was measuring the objectives of the study (Ary et al., 2014). After review of the instrument, minor revisions were made based on suggestions from the expert panel. The University of Florida Institutional Review Board granted permission for the research to be conducted.

Data analysis. The knowledge question responses were condensed into three categories to ease interpretation of the findings. The three condensed categories were not at all knowledgeable/slightly knowledgeable, somewhat knowledgeable, and moderately knowledgeable/extremely knowledgeable. Descriptive statistics, in the form of frequencies and percentages, for the three questions pertaining to the research objectives were then calculated.

\section{Results and discussion}

Growers indicated little familiarity with any of the treatment technologies. With the exception of chemical treatment and vegetated/riparian buffer technologies, more than $50 \%$ of those surveyed indicated only slight or no knowledge of the treatment technologies surveyed (Fig. 1). The lack of familiarity was most pronounced in the case of algal turf scrubbers: $87.4 \%$ of surveyed growers indicated they had only slight or no knowledge of that technology. The technology about which the most growers indicated they had moderate or extreme knowledge was chemical treatment of water for pathogen removal $(32.5 \%)$, followed closely by vegetated/riparian buffers for sediment and nutrient removal (30.5\%).

The water treatment technology most implemented $(23.9 \%)$ was a vegetated buffer/riparian buffer for sediment and nutrient removal (Fig. 2), of which $86.5 \%$ of the growers who had implemented still continue to use (Fig. 3). Mechanical filters and chemical treatments treatment technologies were the second and third most implemented technologies, respectively, and of these adopters a significant number $(85.1 \%$ and $84.1 \%)$ continue to use them in their operations (Fig. 3). By contrast, no respondents had implemented algal turf scrubbers for nutrient removal in their operations. Similarly, only one respondent had adopted the use of carbon/denitrification walls. Although that one respondent continued to use that technology, the parameters 
of the study do not elucidate why this grower chose this unique path.

Treatment technologies that growers indicated they had low to no knowledge of were either newer technologies adaptable to larger-scale operations (algal turf scrubbers and floating wetlands) or technologies that have been used by other industries or sectors of agriculture but that have not been widely adopted yet in the container nursery production industry (bioreactors, carbon walls, activated carbon, filter socks, and constructed wetlands). These seven treatment technologies also tend to be those with moderate or higher initial installation costs (algal turf scrubbers and constructed wetlands); those that require intensive, ongoing maintenance to ensure their continued function (algal turf scrubbers and filter socks); or technologies that are simply less well-known that would require moderate up-front investment, but require some (floating wetlands, activated carbon) or minimal ongoing maintenance (bioreactors and carbon walls) (Majsztrik et al., 2017). A greater percentage of respondents indicated some level of awareness of technologies (chemical treatment and vegetated buffers) that were perceived to have lower initial costs of investment and to be scalable (from small to large) (Majsztrik et al., 2017; Raudales et al., 2014b, 2017).

Treatment technologies were not defined in the survey, and grower responses were based solely on their understanding of the terminology used, which was a limitation of the study. For instance, many growers indicated they had implemented mechanical filters $(23.9 \%)$, but only $12.2 \%$ of growers indicated they had implemented physical treatment technologies, even though mechanical filters are a type of physical treatment technology. Possible misinterpretation of terms may have affected the survey results, such as their reported level of adoption. However, the lack of knowledge highlighted by the survey is also likely to be an important barrier for nursery and greenhouse growers to adopt water treatment technologies in practice. This highlights the need to provide educational opportunities for nursery and greenhouse growers to learn, observe, and have an opportunity to become familiarized with water treatment technologies, with a resulting impact on adoption of water conservation practices. This finding lends itself to Rogers (2003) theoretical diffusion of innovations approach that indicates observability is a key characteristic of an innovation that influences adoption rates.

Our results confirmed the findings of Yeager et al. (2010), who reported that there is hesitation among growers to adopt water treatment technologies. Less than $24 \%$ of the nursery and greenhouse growers indicated that they had implemented a water treatment technology. In a similar study that focused on nursery and greenhouse growers' implementation of water conservation technologies (Warner et al., 2018), it was noted that $58.4 \%$ of the growers had implemented a conservation technology. Between these two studies, there is a $34.5 \%$ difference in implementation of treatment technologies as compared with conservation technologies. However, Warner et al. (2018) also indicated that growers were moderately or extremely knowledgeable about the conservation technologies examined in the study, whereas the results of this study indicated that many growers were not at all or slightly knowledgeable about treatment technologies. This observation again highlights the need for future research to be conducted to evaluate if an increase in knowledge elicited by educational efforts around treatment technologies can lead to an increase in implementation.

The continued use of treatment technologies after they have been used initially portrays a more positive movement toward the adoption of water treatment technologies. Of the growers who did implement the treatment technologies, the majority continued to use 10 of the 12 treatment technologies. Presumably, growers were able to experience the positive impacts of implementing these technologies (Wilson and von Broembsen, 2017), which led to the continued use of these technologies. If growers experience positive effects following the implementation and adoption of water treatment technologies, then there is a great opportunity for the adopting growers to advocate to nonadopting growers the benefits of using treatment technologies. This indicates that there is an opportunity for growers to host nonadopting growers at their operations for educational purposes, and that this would provide an opportunity for nonadopting growers to see the technologies in action, thereby increasing the likelihood of their adoption of water treatment technologies (Rogers, 2003).

\section{Literature cited}

Ary, D., L.C. Jacobs, C.K. Sorensen, and D.A. Walker. 2014. Introduction to research in education. Wadsworth Cengage Learning, Belmont, CA.

Bakker, K. 2012. Water security: Research challenges and opportunities. Science 337(6097):914-915.

Bartok, J.W., Jr. 2009. Sizing the greenhouse water system. 29 June 2019. <https://ag. umass.edu/greenhouse-floriculture/factsheets/sizing-greenhouse-water-system>.

Bhatnagar, A., W. Hogland, M. Marques, and M. Sillanpäa. 2013. An overview of the modification methods of activated carbon for its water treatment applications. Chem. Eng. J. 219(1):499-511.

Bixio, D., C. Thoeye, T. Wintgens, A. Ravazzini, V. Miska, M. Muston, H. Chikurel, A. Aharoni, D. Joksimovic, and T. Melin. 2006. Water reclamation and reuse: Implementation and management issues. Desalination 218(1-3):13-23.

Field, A. 2013. Discovering statistics using IBM SPSS statistics. 4th ed. Sage Publ., London, England.

Fulcher, A., A.V. LeBude, J.S. Owen, S.A. White, and R.C. Beeson. 2016. The next ten years: Strategic vision of water resources for nursery producers. HortTechnology 26:121-132.

Grey, D. and C.W. Sadoff. 2007. Sink or swim? Water security for growth and development. Water Policy 9(6):545-571.

Hardesty, D.M. and W.O. Bearden. 2004. The use of expert judges in scale development: Implications for improving face validity of measures of unobservable constructs. J. Bus. Res. 57(2):98-107.

Haynes, S.N., D. Richard, and E.S. Kubany. 1995. Content validity in psychological assessment: A functional approach to concepts and methods. Psychol. Assessment 7(3):238-247.

Kline, R. and T. Pinch. 1996. Users as agents of technological change: The social construction of the automobile in the rural United States. Technol. Cult. 37(4):763795. 
Levine, A.D., G. Tchobanoglous, and T. Asano. 1985. Characterization of the size distribution of contaminants in wastewater: Treatment and reuse implications. J. Water Pollution Control 57:805-816.

Majsztrik, J.C., R.T. Fernandez, P.R. Fisher, D.R. Hitchcock, J. Lea-Cox, J.S. Owen, Jr., L.R. Oki, and S.A. White. 2017. Water use and treatment in containerized specialty crop production: A review. Water Air Soil Pollut. 228:151.

Raudales, R.E., J.L. Parke, C.L. Guy, and P.R. Fisher. 2014a. Control of waterborne microbes in irrigation: A review. Agr. Water Mgt. 143(C):9-28.

Raudales, R.E., T.A. Irani, C.R. Hall, and P.R. Fisher. 2014b. Modified Delphi survey on key attributes for selection of watertreatment technologies for horticulture irrigation. HortTechnology 24:355-368.

Raudales, R.E., P.R. Fisher, and C.R. Hall. 2017. The cost of irrigation sources and water treatment in greenhouse production. Irr. Sci. 35(1):43-54.
Ray, N.E., D.E. Terlizzi, and P.C. Kangas 2015. Nitrogen and phosphorus removal by the algal turf scrubber at an oyster aquaculture facility. Ecol. Eng. 78:27-32.

Rogers, E.M. 2003. Diffusion of innovations. Free Press, New York, NY.

Schmidt, C.A. and M.W. Clark. 2012. Efficacy of a denitrification wall to treat continuously high nitrate loads. Ecol. Eng. 42:203-211.

Tran, M., E. Koncagul, and R. Connor. 2016. 2016-Water and jobs: Facts and figures. United Nations Educational, Scientific, and Cultural Organization. World Water Assessment Programme, Perugia, Italy.

Warner, L.A., A.J. Lamm, P.N. Beattie, S.A. White, and P.R. Fisher. 2018. Identifying opportunities to promote water conservation practices among nursery and greenhouse growers. HortScience 53:958962.

White, S.A. 2013. Wetland technologies for nursery and greenhouse compliance with nutrient regulations. HortScience 48:1103-1108.

Wilson, P.C., C. Riiska, and J.P. Albano. 2010. Nontarget deposition and losses of chlorothalonil in irrigation runoff water from a commercial foliage plant nursery. J. Environ. Qual. 39(6):2130-2137.

Wilson, S.K. and S. von Broembsen. 2017. Capturing and recycling irrigation runoff as a pollution prevention measure. Oklahoma State Univ., Div. Agr. Sci. Natural Resources, Oklahoma Coop. Ext. Serv. BAE1518. 30 June 2019. <http://pods.dasnr. okstate.edu/docushare/dsweb/Get/ Document-7408/BAE-1518web.pdf>.

Yeager, T., J. Million, C. Larsen, and B. Stamps. 2010. Florida nursery best management practices: Past, present, and future. HortTechnology 20:82-88. 